\title{
Influence of ethical ideology and emotional intelligence on the ethical judgement of future accountants in Malaysia
}

\author{
Suhaiza Ismail \\ Department of Accounting, International Islamic University Malaysia, \\ Kuala Lumpur, Malaysia, and \\ Zuhudha Rasheed \\ International Islamic University Malaysia, Kuala Lumpur, Malaysia
}

Received 10 April 2018 Revised 2 August 2018 27 November 2018

\begin{abstract}
Purpose - This paper aims to identify the influence of personal factors on the ethical judgement of future accountants in Malaysia. In particular, there are two research objectives for this study: first, to investigate the influence of ethical ideology on the ethical judgement of accounting students and second, to investigate the influence of emotional intelligence (EI) on ethical judgement.
\end{abstract}

Design/methodology/approach - The respondents of the study were final year undergraduate accounting students from three public universities in Malaysia. A survey questionnaire comprising instruments about ethical ideology, EI and ethical judgement was distributed. A total of 205 responses were received and were deemed as useable. To achieve the research objectives, multiple regression was performed.

Findings - The findings indicate that idealism and EI have a positive influence on the ethical judgement. In contrast, the study discovered that relativism influences ethical judgement negatively.

Originality/value - This study fills the research gap as research on personal factors on the ethical judgement of future accountants is very limited and scarce. It gives insights to the various parties concerning how to enhance ethical judgement among future accountants, which ultimately will improve the credibility of the accounting profession.

Keywords Malaysia, Emotional intelligence, Ethical ideology, Accounting students,

Personal factors, Future accountants

Paper type Research paper

\section{Introduction}

Accountants contribute significantly to the economic growth of the nation, they are responsible for safeguarding the public interest and to ensure the good management of public and private finance. The former president of the Association of Chartered Certified Accountant Malaysia, Datuk Mohd Nasir Ahmad claimed that "Accountants play a pivotal role in driving the growth of the economy and assume a 'gate-keeper' function to ensure effective running of the financial ecosystem" (Gradmalaysia.com 2013; Ismail, 2015).

More importantly, accountants have special obligations to behave ethically because of the considerable trust that investors and creditors place in them (Stanga and Turpen, 1991). However, recent high-profile corporate ethical scandals involving accountants, such as Enron, WorldCom and Arthur Anderson have to some extent, damaged the reputation of the accounting profession. Likewise, in the context of Malaysia, the reputation of the accounting 
MEDAR 27,6

806

profession has been badly tarnished by reported ethical scandals, such as Bumiputra Bank, Pan-Electric Industries, Johari Abas and Anor and David Low See Keat and Orsants where accountants were used by their clients due to their ethical misconduct (Adam Bakar et al., 2003; Shiong 2006; Adam Bakar et al., 2003; Mohamad and Muhamad, 2011).

Personal factors such as ethical ideology and emotional intelligence (EI) are important factors that can influence the ethical judgment of individuals. Lan et al. (2009) opined that the way individuals behave is shaped by their personal values. Individuals' values drive them to act ethically or unethically in pursuit of their goals. The likelihood that individuals will behave unethically depends to some extent on the personal values motivating them to evaluate their actions. More importantly, the significance of personal factors has been highlighted in a number of ethical decision-making models, such as in Ferrell and Gresham (1985), Hunt and Vitell (1986), Trevino (1986), Rest (1986) and Jones, 1991. In addition, O'Fallon and Butterfield (2005) in their review of prior studies on the ethical decisionmaking called for more empirical works on individual (personal) influences on the ethical judgment.

Although these scandals are committed by accountants who are already part of the profession, Ho et al. (2006) argued that the universities should play an important role in solving the ethical issues that are currently pervading the accounting profession by making sure that universities are producing future accountants that are more ethical. Future accountants are the present accounting students who will have to uphold this responsibility held in the near future. Hence, the future of the accounting profession depends on the ethical standards of accounting students currently enrolled in the university. Moreover, prior studies on ethics have given very little attention to students' ethical judgement, specifically, the impact of individual personal factors on ethical judgement. Hence, the present study attempts to address this gap by examining the influence of personal factors on the ethical judgement of future accountants. Specifically, the present study investigates the influence of personal factors - the ethical ideology and EI - on the ethical judgement of future accountants in Malaysian public universities.

This study is significant in a number of ways. Firstly, there were a few prior studies pertaining to ethical judgment among future accountants. This study may help to contribute to the existing literature on students' ethical judgment, particularly, in the context of developing countries, such as Malaysia. Thus, it is hoped that this study will fill the gap in the literature of ethics research on future accountants, which may certainly contribute to the sparse literature on the ethical judgement in this region. Secondly, this study uses final year accounting students as the respondents; hence, the findings may assist accounting practitioners and employers in understanding the ethical judgment of their prospective employees as employers will then be able to set their future expectations of recruitment and selection strategies. Similarly, identifying the moral potentiality of the future business leaders may help to determine future training needs of their employees. Thirdly, this study may provide a better understanding of the ethical decision-making ability of the undergraduate accounting students who are about to start their accounting career. Also, this study provides a platform to elaborate ethics research in social science in general, such as on students from other disciplines, including economics, finance and business.

The remaining part of this study is structured as follows. The following section reviews the relevant literature and proposes hypotheses for the study. The subsequent section describes the research methodology and procedures used in undertaking this study. Following this, the findings and results are discussed. The study concludes by identifying the implications and limitations of the study, in addition to offering suggestions for future studies. 
Literature review and hypotheses development

Ethical ideology and ethical judgement

Ethical ideology is "a system of ethics used to make a moral judgement, which offers guidelines for judging and resolving behaviour that may be ethically questionable" (Henle et al., 2005). It is the set of beliefs, attitudes and values that may provide individuals with a framework within which to consider ethical dilemmas (Forsyth and Nye, 1990). Schlenker and Forsyth (1977) and Forsyth (1980) suggested that differences in individual moral philosophies can be parsimoniously described as two basic dimensions: relativism and idealism. Relativism refers to the extent to which an individual rejects universal moral rules. Highly relativistic individuals perceive that moral actions depend on the nature of the situation and the individuals involved, and when making ethical judgment they weigh the circumstances more than the ethical principle that was violated. In contrast, low relativism individuals argue that morality requires acting in ways that are consistent with moral principles, norms or laws. The second dimension, idealism, describes the individual's concern for the welfare of others. The extreme idealistic persons assume that desirable consequences can, with the "right" action, always be obtained. They would rather not choose between the lesser of two evils, which will lead to negative consequences for other people. Those with a less idealistic orientation, however, admit that harm will sometimes be necessary to produce a positive impact.

Previous studies have shown that variations of ethical ideology may predict individual differences in ethical judgment (Wuensch et al., 1998; Eastman et al., 2001; Marques and Pereira, 2009; Douglas et al., 2001; Henle et al., 2005; Hastings et al., 2010). Idealism was found by many previous empirical studies to influence ethical judgment in a more positive manner (Forsyth and Nye, 1990; Bruns and Merchant, 1990; Trevino and Victor, 1992; Giacalone et al., 1995; Bass et al., 1998; Henle et al., 2005; Ramsey et al., 2007; Greenfield et al., 2008; Ameh et al., 2010; Yuhanis and Ismail, 2018). Prior evidence suggests that highly idealistic individuals, who believe that it is possible to avoid harm to others if the morally right action is undertaken, have been reported to judge unethical matters more strictly (Forsyth, 1980, 1981,1985). For example, Arrington and Reckers (1985), claimed that more idealistic individuals judged tax evasion as more serious and more likely to view tax compliance as a social norm. Douglas et al. (2001) found that more idealistic auditors rated questionable actions more negatively. A study by Greenfield et al. (2008) found that idealistic individuals were less likely to engage in earnings management behaviour, earnings management and auditing tasks, respectively. Barnett et al. (1994), who used business students as respondents, also reported in favour of idealism. However, the inconsistent result was discovered by Marques and Pereira (2009) on Portuguese chartered accountants.

On the other hand, highly relativist individuals who strongly reject absolute rules and law, but closely investigate the situational factors that contribute to one's action, have a tendency to be more lenient in making ethical decisions (Forsyth, 1980, 1981,1985; Vitell and Singhapakdi, 1993). A similar result was also discovered by Arrington and Reckers (1985), Shaub et al. (1993), Greenfield et al. (2008) and Callanan et al. (2010), who reported that highly relativistic individuals were less sensitive to ethical situations. However, an insignificant relationship between relativism and judgment was revealed by Barnett et al. (1994) and Marques and Pereira (2009).

Despite the various prior studies on ethical ideology, it is also observed that little research in this area has been conducted in Malaysia with respect to future accountants.

Despite numerous prior studies that have investigated the relationship between ethical ideologies and ethical decision making, there is a scarcity of studies from the Eastern region,

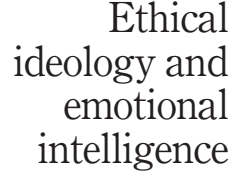

807 
MEDAR 27,6

\section{8}

which includes Malaysia, as reported by Forsyth et al. (2008) in their meta-analytic study. Moreover, prior studies on ethical ideology and ethical judgment in accounting majors have mostly focussed on accounting practitioners and little attention has been paid to accounting students as the subject matter. It is crucial to examine the ethical ideology and ethical judgment of the future accountants as they have almost completed the study programme and will join the profession soon, and to some extent, will have an impact on the future direction of the profession. Hence, this present study intends to extend existing empirical studies on the impact of ethical ideology on ethical judgment focussing on future accountants, particularly in Malaysia. Based on the discussion on the ethical ideology and ethical judgment and the review of empirical evidence of prior literature, the following hypotheses were proposed:

H1a. Idealism is positively associated with the ethical judgement of future accountants.

H1b. Relativism is negatively associated with the ethical judgement of future accountants.

\section{Emotional intelligence and ethical judgement}

$\mathrm{EI}$ is "the ability to monitor one's own and others' emotions, to discriminate among them, and to use the information to guide one's thinking and actions" (Salovey and Mayer, 1990, p. 189). It is an individual or personal distinct factor in managing one's own and others' emotion to guide the necessary thinking and action to successfully cope with environmental demands and pressures (Van Rooy and Viswesvaran, 2004; Mesmer-Magnus et al, 2008). EI is a concept that has received a great deal of scholarly attention in the social science literature. A large body of research has shown that emotion impacts the individual's cognitive processes in different ways (Archer et al., 1996; Kline et al., 2002; Tversky and Fox, 1995; Tversky and Kahneman, 1981; Slovic et al., 2002; Townsend et al., 2000).

EI can be a positive factor for successful interactions (Jordan et al., 2002). For instance, Lopes et al. (2003) found that high EI persons were more likely to report positive relations with others and less likely to report negative interactions with close friends. In a series of studies, Law et al. (2004) found that EI predicted positive social and work-related outcomes and was distinct from personality. Eshun et al. (2010) investigated the role of EI on organisational decision-making among college students. Their results indicated that respondents with higher EI were significantly more likely to make better decisions than those with low EI.

The relationship between emotion and behaviour leads to changes between the individual and the environment (Folkman and Lazarus, 1988). Individuals with a high-level of EI will be able to manage their emotions and react less aggressively to the behaviour of others. Connelly et al. (2004) stated that awareness of one's own negative emotions can be useful in reducing their respective impact on ethical judgements. Much of the research on emotion and cognition examines the impact of positive or negative emotions on decision making, problem solving and evaluation tasks (Bower, 1981; Isen, 1993; Staw and Barsade, 1993).

EI may also have an impact on the ethical decisions of an individual. MesmerMagnus et al. (2008, 2010), Deshpande and Joseph (2009), Angelidis and Ibrahim (2011) and Ismail (2015) discovered that individuals with high EI tend to act more ethically than those with lower EI. Except those few studies, very little research has been done on the relationship between EI and ethical judgment. This has been highlighted by Mesmer-Magnus et al. (2010, p. 36), who stated that "To date, no empirical research has examined the EI-ethical perceptions link". The paucity of research on this relationship 
is of particular concern in the context of the accounting profession and in light of Akers and Porter's (2003, p. 65) that the AICPA and the Institute of Management Accountants "recognize that EI skills are critical for the success of the accounting profession". In light of the above discussion and findings of prior studies, the following hypothesis is formed to explore the influence of EI on the judgement of future accountants:

H2. Future accountants with higher EI are more likely to make judgements that are ethical.

\section{Control variables}

This study considered two control variables: gender and academic performance, which are elaborated in the following discussion.

\section{Gender}

Researchers have identified gender as an important demographic variable influencing an individual's ethical decisions (Henle et al., 2005; Karande et al., 2002). A review of empirical studies on ethical decision-making by Loe et al. (2000), O'Fallon and Butterfield (2005) and Craft (2013) found that most empirical studies addressing individual factors that influence ethical decision making use gender as a control mechanism, and therefore, generate a greater volume of findings than other single areas. Particularly, the role of gender in ethical decision making has received significant examination in business. The bulk of studies found significant gender differences, with woman tending to be more ethically sensitive than men. Perhaps, the use of a student sample is adequate. Although there has been an abundance of studies that have investigated the influence of gender on ethical judgement, the results have been inconsistent. Several studies reported that women have higher ethical attitudes than men (Akaah and Riordan, 1989; Cohen et al., 2001; Dawson, 1997; Ruegger and King, 1992; Weeks et al., 1999). There were also studies that found no significant differences between the ethical judgements of men and women (Hartikainen and Torstila, 2004; Radtke, 2000; Serwinek, 1992; Shafer et al., 2001; Sikula and Costa, 1994; Stanga and Turpen, 1991). Mixed results for the impact of gender on ethical decision making were found in the previous literature review and the trend has continued in more recent studies (Bampton and Maclagan, 2009; Elango et al., 2010; Eweje and Brunton, 2010; Herington and Weaven, 2008; Krambia-Kapardis and Zopiatis, 2008; Marta et al., 2008; Nguyen et al., 2008b; Oumlil and Balloun, 2009; Sweeney et al., 2010; Valentine and Rittenburg, 2004; Haron et al., 2014).

\section{Academic performance}

Academic performance is another control determinant for ethical decision making, as in the context of the relationship between education and ethical judgement several studies have supported the idea that more educated individuals were found to be more ethical (Browning and Zabriskie, 1983; Jones and Gautschi, 1988; Razzaque and Hwee, 2002; Swaidan et al., 2003). However, other relationship studies, such as those of Deshpande (1997), Dubinsky and Ingram (1984), Kidwell et al. (1987), Merritt (1991) and Shafer et al. (2001), found no evidence that education is related to ethical judgement.

\section{Research methodology \\ Data collection}

In undertaking this study, a questionnaire survey was used to investigate the influence of personal factors on the ethical judgement of the future accountants of Malaysia. The respondents 
MEDAR 27,6

810

of the present study were final year accounting students. University students were chosen because they will become the accountants of tomorrow, and as such, it is necessary to identify their ethical stance (Sedmak and Nastav, 2010). The survey questionnaires were distributed to three Malaysian public universities. The three selected universities are established public universities that have been offering the accounting degree programme for many years. Although there are several other public universities that are also offering an accounting degree programme, because of the time and cost constraints, only three universities are covered in the present study. However, as the accounting degree programme in all the public universities in Malaysia has a standardised curriculum based on Halatuju, to some extent, the findings of the current study, may also be generalised to accounting students in other universities.

The students completed the survey instruments during their last semester between March and April 2015. The process of questionnaire distribution was assisted by lecturers of the selected universities who are teaching final year courses. In total, 80 questionnaires were distributed to each university, hence, a total of 240 questionnaires was distributed. The questionnaire took an average 5 to $10 \mathrm{~min}$ to complete. A week subsequent to the distribution of the questionnaires, the lecturers helped collect the completed questionnaires from the students and submitted them to the researcher. In total, 205 respondents completed the questionnaire, representing a response rate of approximately 85.4 per cent.

\section{Research instrument}

The self-administered questionnaire used in this study is adapted with permission from previous studies, including Forsyth (1980) and Wong and Law (2002). Appendix displays the research instrument used in the present study. The questionnaire survey consists of four parts (Parts A to D). The general instructions request that respondents answer all parts of the questionnaire and detailed instructions accompany each part to encourage the respondents to answer the questions.

Part A consists of three questions pertaining to demographic information, which includes, gender, year of study and cumulative grade point average (CGPA). Ultimately, the main purpose of gathering the respondent's demographic information is to ensure their credibility. The main objective is to target final year accounting students. Part $\mathrm{B}$ of the questionnaire is targeted to measure the respondents' ethical ideology using the ethical position questionnaire (EPQ) by Forsyth (1980). This instrument is based on the general idea of moral values and the more specific concept of moral philosophies based on two factors, related to relativism and idealism. EPQ consists of 20 items of which ten items examine idealism and the remaining ten items examine relativism. The EPQ presents a series of statements with which respondents in the current study were asked to indicate their level of agreement on a five-point Likert scale ( 1 being "strongly disagree" and 5 being "strongly agree"). The idealism and relativism scores were computed by averaging the responses to the ten items of the idealism and relativism construct.

Part $\mathrm{C}$ of the questionnaire requires respondents to respond to six vignettes on ethical scenarios adopted from Emerson et al. (2007), which were initially developed by Longer Necker et al. (1989), Clark (1966) and Harris (1991). Adopting vignettes from previously validated instruments tends to increase the reliability of the results and the consistency of the approach in line with the vignettes used in empirical business ethics literature (Ismail, 2014). These six vignettes gauge the ethical judgement of accounting students based on their response to the ethical dilemmas. For each scenario, the respondents were asked to indicate their level of acceptance on a five-point Likert scale (1 being "always acceptable" and 5 being "never acceptable"). Table I below summarises the ethical vignettes used in this present study and provides a description of each vignette in the questionnaire. After reading each scenario, the respondent was asked to indicate the level of acceptability of the action 
taken in each scenario. Thus, a higher score implies a lower acceptance of the ethical scenario or a stricter ethical judgement. A rating of five represents complete disagreement or unacceptability of the action; rating one signifies always acceptable action.

Part D contains an instrument on the EI scales. This study adopts the Wong and Law EI Scale (WLEIS) (Wong and Law, 2002), which is a popular self-report measure of EI. This scale is based on Salovey and Mayer (1990), which Ciarrochi et al. (2000) commented on in a review of the EI literature. WLEIS taps individuals' knowledge about their own emotional abilities rather than their actual capacities. WLEIS suggests that this scale is a reliable and valid self-report index of the ability to monitor and manage emotions (Law et al., 2004; Shi and Wang, 2007; Wong and Law, 2002). The WLEIS consists of 16 items. Examples of the items include "I really understand what I feel". "I always know my friends' emotions from their behaviour", "I always tell myself I am a competent person" and "I have good control of my own emotions". Respondents need to indicate their level of agreement with each statement using a five-point Likert scale (1 being "strongly disagree" and 5 being "strongly agree"). A rating of five represents the complete agreement of the respondent with the EI scales, and a rating of one signifies disagreement with the EI scales.

\section{Data analysis}

In examining, the factors influencing the ethical judgement of future accountants of Malaysia, correlation and multiple regression analysis were conducted to explore the predictive ability of the personal factors on ethical judgement (Pallant, 2007). The independent variables include ethical ideology, which covers two types of ideology: idealism and relativism (X1 and X2) and EI (X3). The control variables are gender and academic performance. The dependent variable is an ethical judgement. The details are outlined below to represent the model of the regression equation.

Model 1:

$$
\mathrm{Y}=\alpha 0+\beta 1 \mathrm{X} 1+\beta 2 \mathrm{X} 2+\beta 3 \mathrm{X} 3+\beta \mathrm{G}+\beta \mathrm{AP}+\varepsilon
$$

where:

$$
\begin{aligned}
\mathrm{Y} & =\text { Ethical judgement } \quad \alpha 0=\text { intercept. } \\
\beta & =\text { Slope of the regression line } \varepsilon=\text { is the error term (RV). } \\
\mathrm{X} & =\text { Independent variables, which includes: } \\
\mathrm{X} 1 & =\text { Idealism. } \\
X 2 & =\text { Relativism. } \\
\mathrm{X} 3 & =\text { EI. } \\
\text { The control variables are outlined below: } & \\
\mathrm{G} & =\text { gender Academic Performance }=\mathrm{AP} .
\end{aligned}
$$

\section{Ethical ideology and emotional intelligence}

811

\begin{tabular}{lll}
\hline Vignette & Brief description \\
\hline A & Exceed legal limit pollution & \\
B & Recommend bad stock & \\
C & Underreport income for tax & \\
D & Cut cost increase risk of harm & Table I. \\
E & Roll-back odometer & Ethical vignettes \\
F & Safety design flaw cover-up & \\
\hline
\end{tabular}


MEDAR

27,6

\section{2}

\section{Findings and discussion}

Demographic information

Table II presents the respondents' demographic profiles in terms of gender, CGPA and year of study. Over two-thirds of the respondents (73.5 per cent) are female and the remaining 55 (26.8 per cent) are male. This ratio reflects the actual population of accounting graduates produced in Malaysia (Ministry of Education, 2012). According to the statistics by the ministry, the ratio of female to male accounting programme students is 3:1 (Ministry of Education, 2012).

In terms of the CGPA of the respondents, the majority (57.6 per cent) is between 3-3.5 points. The second highest CGPA is within the range of 2.5-3 points (25 per cent) of the total respondents, whereas the CGPA range of 3.5 and above cumulating (11.3 per cent). Only 4.4 per cent of the respondents claimed to have a CGPA of 2 to 2.5 points. All the respondents are 4th year accounting students. This cohort was chosen because they are just about to commence their career.

Based on the background information, the respondents of the current study have relevant CGPA and all the respondents are in their fourth year, and about to start their accounting career. Their responses are deemed appropriate and reliable for the current study. The following section discusses the findings of the current study.

\section{Descriptive statistics}

Table III shows the mean scores and standard deviations for all the continuous variables.

For ethical ideology, the mean scores of 3.92 and 3.54 reveal that, on average, respondents rated idealism more highly than relativism. The results mean that, on average, the majority of the students accept universal moral rules and believe that harming others is always avoidable. For EI, the mean score indicates that respondents are able to make use of their emotions by directing them towards constructive activities and personal performance.

The dependent variable of this study is represented by an ethical judgement, as shown in Table IV. The average mean score for the six vignettes was 3.93, where each of the vignettes has a mean score ranging from 3.76 to 4.05 . For the purpose of the

\begin{tabular}{lrr}
\hline & Frequency & $(\%)$ \\
\hline Gender & & \\
Male & 55 & 26.8 \\
Female & 150 & 73.5 \\
Total & 204 & 100.0 \\
CGPA & & \\
$2-2.5$ & 9 & 4.4 \\
$2.5-3.00$ & 51 & 24.9 \\
$3-3.5$ & 118 & 57.6 \\
3.5 and above & 23 & 11.3 \\
Missing data & 4 & 2.0 \\
Total & 205 & 99.0 \\
Year of Study & & \\
4th year & 205 & 100.0 \\
Total & 205 & 100.0 \\
\hline
\end{tabular}

Table II.

Demographic profile of the respondents 
current study, only the average mean score of ethical judgement is used for the multiple regression analysis. The mean score of 3.93 suggests that future accountants perceived ethical dilemmas as unacceptable actions, which to some extent, implies they are ethical. The standard deviation values are all below 1 which is considered as low variation among data sets, and therefore, are acceptable.

Multiple regression analysis

Tables V and VI provide the results of the multiple regression analysis and the Pearson's zero correlation, respectively. Consistent results were revealed by the two analyses as depicted in the two tables.

The results of both analysis reveal that the ethical ideologies of idealism, relativism and EI have a significant influence on an ethical judgement. In terms of ethical ideology, relativism showed a negative significant influence on the ethical judgement of future accountants while idealism showed a positive significant

\begin{tabular}{lccrrr}
\hline Variables & $N$ & Mean & SD & Table III. \\
\cline { 1 - 3 } Ethical Ideology & & & & $\begin{array}{r}\text { Tantist } \\
\text { Idealism }\end{array}$ \\
Relativism & 205 & 3.92 & 0.481 & $\begin{array}{r}\text { Descriptive statistics } \\
\text { of the independent }\end{array}$ \\
Emotional Intelligence & 205 & 3.54 & 0.739 & 0.622 & variables \\
\hline
\end{tabular}

\begin{tabular}{lccc}
\hline Ethical scenarios & $N$ & Mean & SD \\
\hline A - Exceed legal limit pollution & 205 & 4.02 & 0.871 \\
B - Recommend bad stock & 205 & 3.76 & 0.851 \\
C - Underreport income for tax & 205 & 3.98 & 0.910 \\
D - Cut costs, increase risk of harm & 205 & 4.05 & 0.996 Descriptive statistics \\
E- Roll-back odometer & 205 & 3.79 & 0.970 Table IV. \\
F- Safety design flaw cover-up & 205 & 3.98 & 0.987 of respondent's \\
Overall ethical scenarios & 204 & 3.93 & 0.708 ethical judgement \\
\hline
\end{tabular}

\begin{tabular}{|c|c|c|c|c|}
\hline & Standardised coefficient & $t$-value & Significance & \\
\hline Variables & Beta & & & \\
\hline $\begin{array}{l}\text { Ethical ideology: } \\
\text { Idealism } \\
\text { Relativism } \\
\text { Emotional intelligence }\end{array}$ & $\begin{array}{r}0.375 \\
-0.144 \\
0.409\end{array}$ & $\begin{array}{r}5.043 \\
-1.974 \\
4.099\end{array}$ & $\begin{array}{l}0.000^{* * * *} \\
0.053^{*} \\
0.005^{* * * *}\end{array}$ & \\
\hline $\begin{array}{l}\text { Control variable: } \\
\text { Gender } \\
\text { Academic performance } \\
R^{2}=0.23 \\
\text { Adjusted } R^{2}=0.18 \\
\text { Notes: * Significant at } 0\end{array}$ & nificant at 0.01 & $\begin{array}{l}0.886 \\
0.879\end{array}$ & $\begin{array}{l}0.377 \\
0.381\end{array}$ & $\begin{array}{r}\text { Table V. } \\
\text { Multiple regression } \\
\text { analysis }\end{array}$ \\
\hline
\end{tabular}


MEDAR 27,6

\section{4}

influence on an ethical judgement. The results suggest that idealism can lead individuals to make ethical judgements, whereas relativism can lead them to make unethical judgements. The findings are in line with the literature (Arrington and Reckers., 1985; Barnett et al., 1994; Barnett et al., 1996; Bass et al., 1998; Douglas et al., 2001; Callanan et al., 2010; Ismail and Ghazali., 2011; Forsyth, 1980, 1981, 1985; Jones, 1991; Douglas et al., 2001; Greenfield et al., 2008; Yuhanis and Ismail, 2018) but they contradict the findings of the studies by Forsyth and Berger (1982), Forsyth and Nye (1990), Barnett et al. (1994) and Marques and Pereira (2009). Hence, H1a and H1b are supported.

As for EI, it has a significant positive effect on ethical judgement, which implies that future accountants are able to perceive and understand the emotions of people around them and make use of their emotions by directing them towards more ethical judgement. In other words, they are more concerned with the welfare and social well-being of others rather than considering their personal needs. Hence, $H 2 a$ is supported. The results are consistent with the findings of Connelly et al. (2004), Cohen et al. (1995), Leitsch (2004), Karim (2010) and Ismail (2015).

In terms of the control variables, none of the variables showed a significant influence on the ethical judgement. It implies that gender and academic performance do not have an influence on the ethical judgement of future accountants in Malaysia. Although, the current finding is in line with those several studies that found no significant effect of gender on the ethical judgements (Hartikainen and Torstila, 2004; Radtke, 2000; Serwinek, 1992; Shafer et al., 2001; Sikula and Costa, 1994; Stanga and Turpen, 1991), the finding is in contrast to those of prior literature that found that woman tend to be more ethical than men (Akaah and Riordan, 1989; Ruegger and King, 1992; Deshpande, 1997; Borkowski and Ugras, 1992; Singhapakdi et al., 1999; Weeks et al., 1999; Ismail and Ghazali, 2011; Landry et al., 2004; Emerson et al., 2007). In the case of academic performance, a similar finding was reported by researchers, such as Deshpande (1997), Dubinsky and Ingram (1984), Kidwell et al. (1987), Merritt (1991) and Shafer et al. (2001). In contrast, Swaidan et al. (2003) found some support for consumers with the highest level of education to be less tolerant of questionable customer activities.

\section{Implications of the study, limitations and suggestions for future research}

The objective of this study is to investigate the influence of personal factors: ethical ideology and EI on the ethical judgement of future Malaysian accountants. The study used a questionnaire survey distributed to the Malaysian public universities, and drew a total response rate of 81.6 per cent. Based on the results of multiple regression analysis, the respondents' ethical judgement was shown to be significantly influenced

Table VI.

Pearson's zero-order correlations for all variables

\begin{tabular}{|c|c|c|c|c|c|c|c|}
\hline & & 1 & 2 & 3 & 4 & 5 & 6 \\
\hline 1 & Ethical judgement & 1 & & & & & \\
\hline 2 & Idealism & $0.38 * * *$ & 1 & & & & \\
\hline 3 & Relativism & $-0.12 *$ & 0.09 & 1 & & & \\
\hline 4 & EI & $0.36^{* * * *}$ & $0.39 * * *$ & $0.21 * *$ & 1 & & \\
\hline 5 & Gender & 0.06 & $0.15^{* *}$ & 0.04 & $0.17^{*}$ & 1 & \\
\hline 6 & Academic performance & 0.07 & $0.36 * * * *$ & -0.02 & $0.49 * * *$ & $0.24 * *$ & 1 \\
\hline \multicolumn{7}{|c|}{ Notes: $* * * p<0.001 ; * * p<0.05 ; * p<0.10$} & \\
\hline
\end{tabular}


by ethical ideology and EI. The study revealed that the ethical ideology of idealism and EI have a significant positive influence on the ethical judgement of future accountants while relativism has a negative influence.

There are several important implications from the findings of the present study to various parties, such as academics, potential employers and accounting regulators. The results on the positive and negative influence of idealism and relativism, respectively, on ethical judgement, provide useful information to the academics to inculcate the idealism ethical ideology in future accountants as they will be stricter in making ethical related decisions, which ultimately, may improve the credibility of the accounting profession in the near future. This may be achieved if the academics could provide greater exposure to idealism ideology in the classroom. Moreover, inculcating critical thinking skills among the future accountants may also help to furnish the students with the appropriate ethical ideology. In relation to the positive influence of EI on the ethical decisions of the future accountants, academics need to realise that besides accounting knowledge and other relevant technical proficiencies, it is critically important to well-equip the future accountants with positive emotion as it will guide them in making appropriate work-related decisions when they join the workforce.

To the potential employers, the findings on the influence of ethical ideology and EI on the ethical judgement are useful particularly in hiring these future accountants to join their firms/companies. In selecting the new employees, employers may want to carry out a personality assessment that helps to identify candidates with right ethical ideology and appropriate level of EI.

Furthermore, in restoring the credibility of the accounting profession, accounting regulator such as the Malaysian Institute of Accountants may assist the future accountants by providing them with avenues to nurture the idealism ethical ideology and EI. For instance, the accounting regulator may want to organise seminars, training and workshops on spiritual and emotional quotients and a neurolinguistics programme. The employers need to encourage newly hired employees to attend those seminars, training and workshops.

Nonetheless, there are a few limitations of the present study. The sample used in the study only covers accounting students in three universities, and therefore, may not fully represent the population of future accountants in Malaysian public universities. Future research may want to include future accountants from all the public universities in Malaysia that are offering an accounting programme. Moreover, there is a limitation concerning the vignettes used in this study, which are general and not specific to the job scope of an accountant. Moreover, because students lacked wisdom and experience in the work environment, they may behave differently when they are really faced with such situations. It is recommended that future researchers use a practical situation in the classroom, to check the real response to an ethical dilemma faced by a student. In addition, the present study has not considered other personal factors such as age and religion that could have affected the ethical judgement of future accountants. Hence, future studies may want to further investigate by including these useful factors in the analysis. Furthermore, this research used a quantitative survey, which did not allow for capturing the feelings and opinions of the respondents concerning the issue under study. In future, qualitative research techniques, such as interviews and focus groups, can be used to engage the respondents more actively and gain valuable opinions concerning ethical judgements. 
MEDAR

27,6

816

\section{Conclusion}

In conclusion, this study provides relevant information to stimulate more interest in this area of research and pave the way for future studies on the ethical judgement. The empirical findings from this study, to some extent, contribute to the agenda of improving the ethical judgement of accountants, which consequently, will lead to better credibility of the accounting profession.

\section{References}

Adam Bakar, M., Mohamed Saat, M. and Abd. Majid, A. (2003), "Ethics and the accounting profession in Malaysia”, Journal of Financial Reporting and Accounting, Vol. 1 No. 1, pp. 105-122.

Akaah, I.P. and Riordan, E.A. (1989), "Judgments of marketing professionals about ethical issues in marketing research: a replication and extension”, Journal of Marketing Research, Vol. 26 No. 1, pp. $112-120$.

Angelidis, J. and Ibrahim, N.A. (2011), "The impact of emotional intelligence on the ethical judgment of managers", Journal of Business Ethics, Vol. 99, pp. 111-119.

Arrington, C.E. and Reckers, P.M. (1985), "A social-psychological investigation into perceptions of tax evasion", Accounting and Business Research, Vol. 15 No. 59, pp. 163-176.

Barnett, T., Bass, K. and Brown, G. (1994), "Ethical ideology and ethical judgment regarding ethical issues in business", Journal of Business Ethics, Vol. 13 No. 6, pp. 469-480.

Barnett, T., Bass, K. and Brown, G. (1996), "Religiosity, ethical ideology, and intentions to report a peer's wrongdoing", Journal of Business Ethics, Vol. 15 No. 11, pp. 1161-1174.

Bass, K., Barnett, T. and Brown, G. (1998), "The moral philosophy of sales managers and its influence on ethical decision making", Journal of Personal Selling and Sales Management, Vol. 18 No. 2, pp. 1-17.

Borkowski, S.C. and Ugras, Y.J. (1992), "The ethical attitudes of students as a function of age, sex and experience", Journal of Business Ethics, Vol. 11 No. 12, pp. 961-979.

Callanan, G.A., Rotenberry, P.F., Perri, D.F. and Oehlers, P. (2010), "Contextual factors as moderators of the effect of employee ethical ideology on ethical decision-making", International Journal of Management, Vol. 27 No. 1, p. 52.

Cohen, J.R., Pant, L.W. and Sharp, D.J. (1995), "An exploratory examination of international differences in auditors' ethical perceptions", Behavioral Research in Accounting, Vol. 7 No. 1, pp. 37-64.

Cohen, J.R., Pant, L.W. and Sharp, D.J. (2001), “An examination of differences in ethical decision-making between Canadian business students and accounting professionals", Journal of Business Ethics, Vol. 30 No. 4, pp. 319-336.

Connelly, S., Helton-Fauth, W. and Mumford, M.D. (2004), "A managerial in-basket study of the impact of trait emotions on ethical choice", Journal of Business Ethics, Vol. 51 No. 3, pp. 245-267.

Craft, J.L. (2013), “A review of the empirical ethical decision-making literature: 2004-2011”, Journal of Business Ethics, Vol. 117 No. 2, pp. 221-259.

Deshpande, S.P. (1997), "Managers' perception of proper ethical conduct: the effect of sex, age, and level of education", Journal of Business Ethics, Vol. 16 No. 1, pp. 79-85.

Deshpande, S.P. and Joseph, J. (2009), "Impact of emotional intelligence, ethical climate, and behavior of peers on ethical behavior of nurses", Journal of Business Ethics, Vol. 85 No. 3, pp. 403-410.

Douglas, P.C., Davidson, R.A. and Schwartz, B.N. (2001), "The effect of organizational culture and ethical orientation on accountants' ethical judgments”, Journal of Business Ethics, Vol. 34 No. 2, pp. 101-121. 
Emerson, T.L., Conroy, S.J. and Stanley, C.W. (2007), "Ethical attitudes of accountants: recent evidence from a practitioners' survey", Journal of Business Ethics, Vol. 71 No. 1, pp. 73-87.

Eweje, G. and Brunton, M. (2010), "Ethical perceptions of business students in a New Zealand university: do gender, age and work experience matter?", Business Ethics: A European Review, Vol. 19 No. 1, pp. 95-111.

Ferrell, O.C. and Gresham, L.G. (1985), "A contingency framework for understanding ethical decision making in marketing", The Journal of Marketing, Vol. 49 No. 3, pp. 87-96.

Forsyth, D.R. (1980), “A taxonomy of ethical ideologies”, Journal of Personality and Social Psychology, Vol. 39 No. 1, p. 175.

Forsyth, D.R. (1981), "Moral judgment: the influence of ethical ideology", Personality and Social Psychology Bulletin, Vol. 7 No. 2, pp. 218-223.

Forsyth, D.R. (1985), "Individual differences in information integration during moral judgment", Journal of Personality and Social Psychology, Vol. 49 No. 1, pp. 264-272.

Forsyth, D.R. and Berger, R.E. (1982), "The effects of ethical ideology on moral behavior”, The Journal of Social Psychology, Vol. 117 No. 1, pp. 53-56.

Forsyth, D.R. and Nye, J.L. (1990), "Personal moral philosophies and moral choice", Journal of Research in Personality, Vol. 24 No. 4, pp. 398-414.

Forsyth, D.R., O'Boyle, E.H. and McDaniel, J.M.A. (2008), "East meets west: a Meta-Analytic investigation of cultural variations in idealism and relativism", Journal of Business Ethics, Vol. 83 No. 4, pp. 813-833.

Greenfield, A.C., Jr, Norman, C.S. and Wier, B. (2008), "The effect of ethical orientation and professional commitment on earnings management behavior", Journal of Business Ethics, Vol. 83 No. 3, pp. 419-434.

Haron, H., Ismail, I., Ibrahim, D.N. and Aw, L.N. (2014), "Factors influencing ethical judgment of auditors in Malaysia", Malaysian Accounting Review, Vol. 13 No. 2, pp. 47-86.

Hartikainen, O. and Torstila, S. (2004), "Job-related ethical judgment in the finance profession”, Journal of Applied Finance, Vol. 14 No. 1, pp. 62-76.

Henle, C.A., Giacalone, R.A. and Jurkiewicz, C.L. (2005), "The role of ethical ideology in workplace deviance", Journal of Business Ethics, Vol. 56 No. 3, pp. 219-230.

Herington, C. and Weaven, S. (2008), "Improving consistency for DIT results using cluster analysis", Journal of Business Ethics, Vol. 80 No. 3, pp. 499-514.

Ho, Y.H., Jung, C., Lin, C.Y. and Jung, C. (2006), "Can business ethics be taught”, The Journal of Hum Resource and Adult Learning, Vol. 2 No. 1, pp. 33-38.

Hunt, S.D. and Vitell, S. (1986), "A general theory of marketing ethics", Journal of Macromarketing, Vol. 6 No. 1, pp. 5-16.

Ismail, S. (2014), "Effect of ethical ideologies on ethical judgment of future accountants: Malaysian evidence", Asian Review of Accounting, Vol. 22 No. 2, pp. 145-158.

Ismail, S. (2015), "Influence of emotional intelligence, ethical climates and corporate ethical values on ethical judgment of malaysian auditors", Asian Journal of Business Ethics, Vol. 4 No. 2, pp. 147-162.

Ismail, S. and Ghazali, N.A.M. (2011), "Ethical ideology and ethical judgments of accounting practitioners in Malaysia", Gadjah Mada International Journal of Business, Vol. 13 No. 11.

Jones, T.M. (1991), "Ethical decision making by individuals in organizations: an issue-contingent model", Academy of Management Review, Vol. 16 No. 2, pp. 366-395.

Karande, K., Rao, C.P. and Singhapakdi, A. (2002), "Moral philosophies of marketing managers: a comparison of American, Australian, and Malaysian cultures", European Journal of Marketing, Vol. 36 Nos 7/8, pp. 768-791. 
MEDAR 27,6

818

Karim, J. (2010), “An item response theory analysis of wong and law emotional intelligence scale", Procedia-Social and Behavioral Sciences, Vol. 2 No. 2, pp. 4038-4047.

Lan, G., Ma, Z., Cao, J. and Zhang, H. (2009), “A comparison of personal values of Chinese accounting practitioners and students", Journal of Business Ethics, Vol. 88, pp. 59-76.

Landry, R., Moyes, G.D. and Cortes, A.C. (2004), "Ethical perceptions among hispanic students: differences by major and gender", Journal of Education for Business, Vol. 80 No. 2, pp. 102-108.

Law, K.S., Wong, C.S. and Song, L.J. (2004), "The construct and criterion validity of emotional intelligence and its potential utility for management studies", Journal of Applied Psychology, Vol. 89 No. 3, pp. 483.

Leitsch, D.L. (2004), "Differences in the perceptions of moral intensity in the moral decision process: an empirical examination of accounting students", Journal of Business Ethics, Vol. 53 No. 3, pp. 313-323.

Loe, T.W., Ferrell, L. and Mansfield, P. (2000), “A review of empirical studies assessing ethical decision making in business", Journal of Business Ethics, Vol. 25 No. 3, pp. 185-204.

Marques, P.A. and Pereira, J.A. (2009), "Ethical ideology and ethical judgments in the portuguese accounting profession", Journal of Business Ethics, Vol. 86 No. 2, pp. 227-242.

Marta, J., Singhapakdi, A. and Kraft, K. (2008), "Personal characteristics underlying ethical decisions in marketing situations: a survey of small business managers", Journal of Small Business Management, Vol. 46 No. 4, pp. 589-606.

Merritt, S. (1991), "Marketing ethics and education: some empirical findings", Journal of Business Ethics, Vol. 10 No. 8, pp. 625-632.

O'Fallon, M.J. and Butterfield, K.D. (2005), "A review of the empirical ethical decision-making literature: 1996-2003”, Journal of Business Ethics, Vol. 59 No. 4, pp. 375-413.

Radtke, R.R. (2000), "The effects of gender and setting on accountants' ethically sensitive decisions", Journal of Business Ethics, Vol. 24 No. 4, pp. 299-312.

Rest, J.R. (1986), Moral Development: Advances in Research and Theory, Praeger Publishers, Westport.

Ruegger, D. and King, E.W. (1992), "A study of the effect of age and gender upon student business ethics", Journal of Business Ethics, Vol. 11 No. 3, pp. 179-186.

Salovey, P. and Mayer, J.D. (1990), "Emotional intelligence", Imagination, Cognition and Personality, Vol. 9 No. 3, pp. $185-211$.

Serwinek, P.J. (1992), "Demographic and related differences in ethical views among small businesses", Journal of Business Ethics, Vol. 11 No. 7, pp. 555-566.

Shafer, W.E., Morris, R.E. and Ketchand, A.A. (2001), "Effects of personal values on auditors' ethical decisions", Accounting, Auditing and Accountability Journal, Vol. 14 No. 3, pp. 254-277.

Shaub, M.K., Finn, D.W. and Munter, P. (1993), "The effects of auditors' ethical orientation on commitment and ethical sensitivity", Behavioral Research in Accounting, Vol. 5 No. 1, pp. 145-169.

Sikula, A., Sr. and Costa, A.D. (1994), “Are age and ethics related?”, The Journal of Psychology, Vol. 128 No. 6, pp. 659-665.

Stanga, K.G. and Turpen, R.A. (1991), "Ethical judgments on selected accounting issues: an empirical study", Journal of Business Ethics, Vol. 10 No. 10, pp. 739-747.

Swaidan, Z., Vitell, S.J. and Rawwas, M.Y. (2003), "Consumer ethics: determinants of ethical beliefs of African Americans”, Journal of Business Ethics, Vol. 46 No. 2, pp. 175-186. 
Trevino, L.K. (1986), "Ethical decision making in organizations: a person-situation interactionist model", Academy of Management Review, Vol. 11 No. 3, pp. 601-617.

Valentine, S.R. and Rittenburg, T.L. (2004), "Spanish and American business professionals' ethical evaluations in global situations", Journal of Business Ethics, Vol. 51 No. 1, pp. 1-14.

Weeks, W.A., Moore, C.W., McKinney, J.A. and Longenecker, J.G. (1999), "The effects of gender and career stage on ethical judgment", Journal of Business Ethics, Vol. 20 No. 4, pp. 301-313.

Wong, C.S. and Law, K.S. (2002), "The effects of leader and follower emotional intelligence on performance and attitude: an exploratory study", The Leadership Quarterly, Vol. 13 No. 3, pp. 243-274.

Yuhanis, N. and Ismail, S. (2018), "Ethical work behaviour of public sector auditors in Malaysia", AsiaPacific Journal of Business Administration, Vol. 10 No. 1, pp. 21-34.

\section{Further reading}

Bay, D. and McKeage, K. (2006), "Emotional intelligence in undergraduate accounting students: preliminary assessment", Accounting Education: An International Journal, Vol. 15 No. 4, pp. $439-454$.

Davis, M.A., Andersen, M.G. and Curtis, M.B. (2001), "Measuring ethical ideology in business ethics: a critical analysis of the ethics position questionnaire", Journal of Business Ethics, Vol. 32 No. 1, pp. 35-53.

Demirtas, O. (2015), "Ethical leadership influence at organizations: evidence from the field”, Journal of Business Ethics, Vol. 126 No. 2, p. 273.

Douglas, P.C. and Wier, B. (2000), "Integrating ethical dimensions into a model of budgetary slack creation", Journal of Business Ethics, Vol. 28 No. 3, pp. 267-277.

Douglas, P.C. and Wier, B. (2005), "Cultural and ethical effects in budgeting systems: a comparison of US and Chinese managers", Journal of Business Ethics, Vol. 60 No. 2, pp. 159-174.

Forsyth, D.R. (1992), "Judging the morality of business practices: the influence of personal moral philosophies", Journal of Business Ethics, Vol. 11 Nos 5/6, pp. 461-470.

Ismail, S. and Yussof, S.H. (2016), "Cheating behaviour among accounting students: some Malaysian evidence", Accounting Research Journal, Vol. 29 No. 1, pp. 20-33.

Lubit, R. (2004), "The tyranny of toxic managers: applying emotional intelligence to deal with difficult personalities", Ivey Business Journal, Vol. 68 No. 4, pp. 1-7.

Modassir, A. and Singh, T. (2008), "Relationship of emotional intelligence with transformational leadership and organizational citizenship behavior", International Journal of Leadership Studies, Vol. 4 No. 1, pp. 3-21.

Mohd Ghazali, N.A. and Ismail, S. (2013), "The influence of personal attributes and organizational ethics position on accountants' judgments: Malaysian scenario", Social Responsibility Journal, Vol. 9 No. 2, pp. 281-297.

Mulki, J.P., Jaramillo, J.F. and Locander, W.B. (2009), "Critical role of leadership on ethical climate and salesperson behaviors", Journal of Business Ethics, Vol. 86 No. 2, pp. 125-141.

Redfern, K. and Crawford, J. (2004), "An empirical investigation of the influence of modernisation on the moral judgements of managers in the people's republic of China”, Cross Cultural Management: An International Journal, Vol. 11 No. 1, pp. 48-61.

Salleh, M.I.M., Hamid, H.A., Alias, N.R., Ismail, M.N. and Yusoff, Z. (2011), "The influence of gender and age on the undergraduate's academic dishonesty behaviours", Sociality and Economics Development, pp. 593-597.

Smith, M., Ghazali, N. and Fatimah Noor Minhad, S. (2007), "Attitudes towards plagiarism among undergraduate accounting students: Malaysian evidence", Asian Review of Accounting, Vol. 15 No. 2, pp. 122-146. 
MEDAR

27,6

820
Stead, W.E., Worrell, D.L. and Stead, J.G. (1990), "An integrative model for understanding and managing ethical behavior in business organizations", Journal of Business Ethics, Vol. 9 No. 3, pp. 233-242.

Wong, C.S., Law, K.S. and Wong, P.M. (2004), "Development and validation of a forced choice emotional intelligence measure for Chinese respondents in Hong Kong", Asia Pacific Journal of Management, Vol. 21 No. 4, pp. 535-559.

\section{Corresponding author}

Suhaiza Ismail can be contacted at: suhaiza@iium.edu.my 

1. Gender:
Female
Male
2. Year of Study:
$2^{\text {nd }}$ year
$3^{\text {rd }}$ year
$\square 4^{\text {th }}$ year
3. CGPA:
$\square 2 \geq 2.5 \square 2.5 \geq 3.00$
$3 \geq 3.5$
3.5 and above

PART B: ETHICAL IDEOLOGY

INSTRUCTION: Please indicate the extent to which you agree or disagree with the following statement by putting a CIRCLE in the appropriate box.

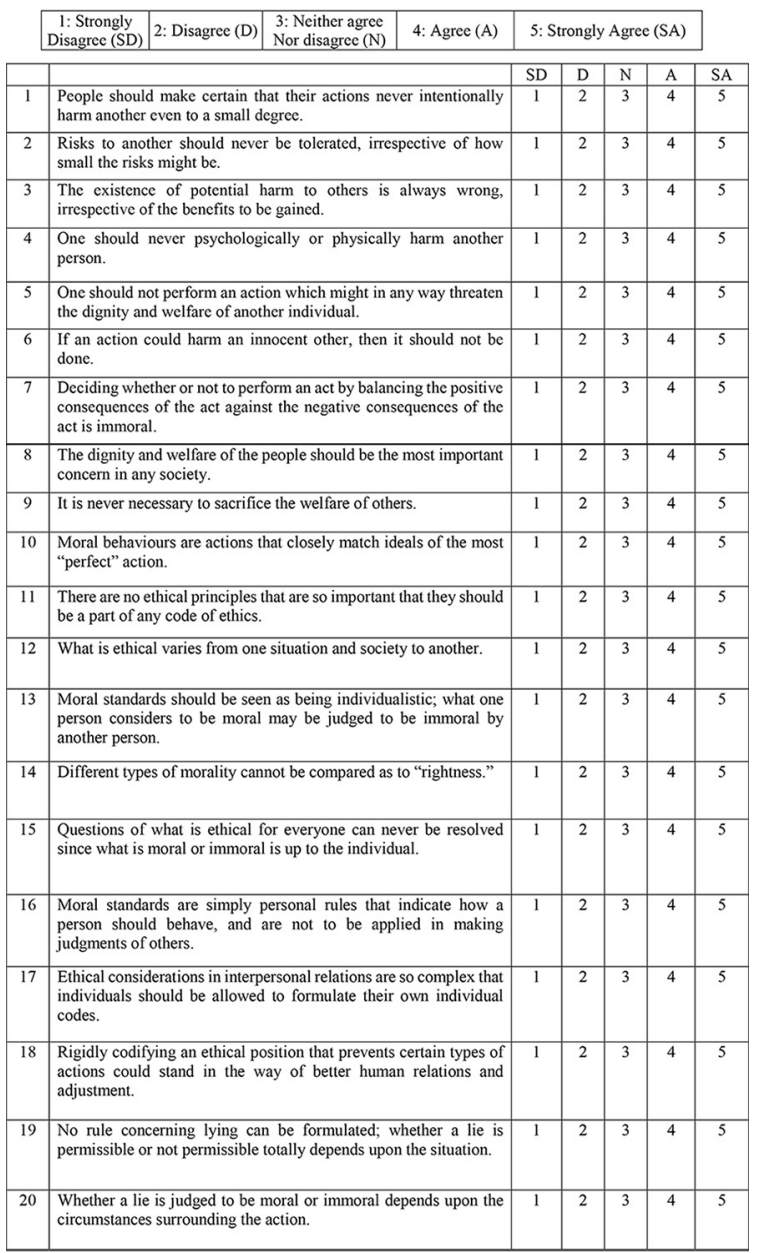

(contimued) 
MEDAR

27,6

822

\section{PART C: ETHICAL VIGNETTES}

INSTRUCTION: Please indicate the degree to which you feel the behaviour described in each scenario is ethically acceptable to placing a CIRCLE the appropriate number on the five-point scale, where 1 is "always acceptable" and 5 is "never acceptable".

\begin{tabular}{|l|l|l|l|l|l|l|}
\hline & \multicolumn{3}{|l|}{$\begin{array}{l}\text { Always } \\
\text { acceptable }\end{array}$} & \multicolumn{3}{|l|}{$\begin{array}{l}\text { Never } \\
\text { Acceptable }\end{array}$} \\
\hline A & $\begin{array}{l}\text { In order to increase profit of the firm, a general manager } \\
\text { used production process that exceeded legal limits for } \\
\text { environmental pollution. }\end{array}$ & 1 & 2 & 3 & 4 & 5 \\
\hline B & $\begin{array}{l}\text { Because of pressure from his brokerage firm, a broker } \\
\text { recommended a type of share which he did not consider to } \\
\text { be a good investment. }\end{array}$ & 1 & 2 & 3 & 4 & 5 \\
\hline C & $\begin{array}{l}\text { A small business received one- fourth of its gross revenue } \\
\text { in the form of cash. The owner reported only one-half of } \\
\text { the cash receipts for income tax purposes. }\end{array}$ & 1 & 2 & 3 & 4 & 5 \\
\hline D & $\begin{array}{l}\text { The design department of XYZ Child Corporation } \\
\text { recently developed a new, lighter weight baby carrier. The } \\
\text { new design is less expensive to manufacture, but has } \\
\text { slightly higher risk to handle collapse which could cause } \\
\text { injury to children. XYZ decided to produce and market the } \\
\text { carrier anyway. }\end{array}$ & 1 & 2 & 3 & 4 & 5 \\
\hline E & $\begin{array}{l}\text { Jack is used car salesman who was under pressure from } \\
\text { his boss to increase the sales in order for the company to } \\
\text { survivc. In response, he began rolling back odometers and } \\
\text { using high pressure sales tactics. }\end{array}$ & 1 & 2 & 3 & 4 & 5 \\
\hline F & $\begin{array}{l}\text { An cngincer discovered what he perceived to be a product } \\
\text { design flaw that constituted a safety hazard. His company } \\
\text { declined to correct the flaw. The engineer decided to keep } \\
\text { quiet, rather than taking his complaint outside the } \\
\text { company. }\end{array}$ & 1 & 2 & 3 & 4 & 5 \\
\hline
\end{tabular}

\section{PART D: EMOTIONAL INTELLIGENCE}

INSTRUCTIONS: Please indicate your level of agreement with each of the following statements by putting a CIRCLE in the appropriate box.

\begin{tabular}{|c|l|c|c|c|c|c|}
\hline & & SD & D & N & A & SA \\
\hline 1 & $\begin{array}{l}\text { I have a good sense of why I have certain feelings most } \\
\text { of the time. }\end{array}$ & I & 2 & 3 & 4 & 5 \\
\hline 2 & I have good understanding of my own emotions. & 1 & 2 & 3 & 4 & 5 \\
\hline 3 & I really understand what I feel. & 1 & 2 & 3 & 4 & 5 \\
\hline 4 & I always know whether or not I am happy. & 1 & 2 & 3 & 4 & 5 \\
\hline 5 & $\begin{array}{l}\text { I always know my friends' emotions from their } \\
\text { behavior. }\end{array}$ & 1 & 2 & 3 & 4 & 5 \\
\hline 6 & I am a good observer of others' emotions. & 1 & 2 & 3 & 4 & 5 \\
\hline 7 & I am sensitive to the feelings and emotions of others. & 1 & 2 & 3 & 4 & 5 \\
\hline 8 & $\begin{array}{l}\text { I have good understanding of the emotions of people } \\
\text { around me. }\end{array}$ & 1 & 2 & 3 & 4 & 5 \\
\hline 9 & $\begin{array}{l}\text { I always set goals for myself and then try my best to } \\
\text { achieve them. }\end{array}$ & 1 & 2 & 3 & 4 & 5 \\
\hline 10 & I always tell myself I am a competent person. & 1 & 2 & 3 & 4 & 5 \\
\hline 11 & I am a self-motivating person. & 1 & 2 & 3 & 4 & 5 \\
\hline 12 & I would always encourage myself to try my best. & 1 & 2 & 3 & 4 & 5 \\
\hline 13 & $\begin{array}{l}\text { I am able to control my temper so that I can handle } \\
\text { difficulties rationally. }\end{array}$ & 1 & 2 & 3 & 4 & 5 \\
\hline 14 & I am quite capable of controlling my own emotions. & 1 & 2 & 3 & 4 & 5 \\
\hline 15 & I can always calm down quickly when I am very angry. & 1 & 2 & 3 & 4 & 5 \\
\hline 16 & I have good control of my own emotions. & 1 & 2 & 3 & 4 & 5 \\
\hline
\end{tabular}

Thank you for your kind cooperation in completing the questionnaire. 